\title{
UCCE's connection to the community continues
}

\section{Introduction}

$\mathrm{UC}$ Division of Agriculture and Natural Resources (ANR) research - on campuses, at research and extension centers and in Cooperative Extension offices throughout the state - focuses on critical issues in California's agriculture, natural resources, youth development and nutrition. Five strategic initiatives in UC ANR provide collaborative opportunities for addressing these issues: Endemic and Invasive Pests and Diseases; Healthy Families and Communities; Sustainable Food Systems; Sustainable Natural Ecosystems; and Water Quality, Quantity and Security. These initiatives look for new approaches, new resources and new partnerships within and outside UC to identify, communicate and solve these problems. The five Cooperative Extension projects highlighted in this article represent these five strategic initiatives.

Today, in its 100th year of service, UC Cooperative Extension (UCCE) is as connected to California communities as ever. UCCE advisors provide expertise and practical, science-based solutions on a wide range of subjects - from family health to food production to water quality to invasive pests - and have a keen understanding of local issues because they live and work in the communities they serve. The following are just a few examples of the many ways UCCE benefits Californians now.

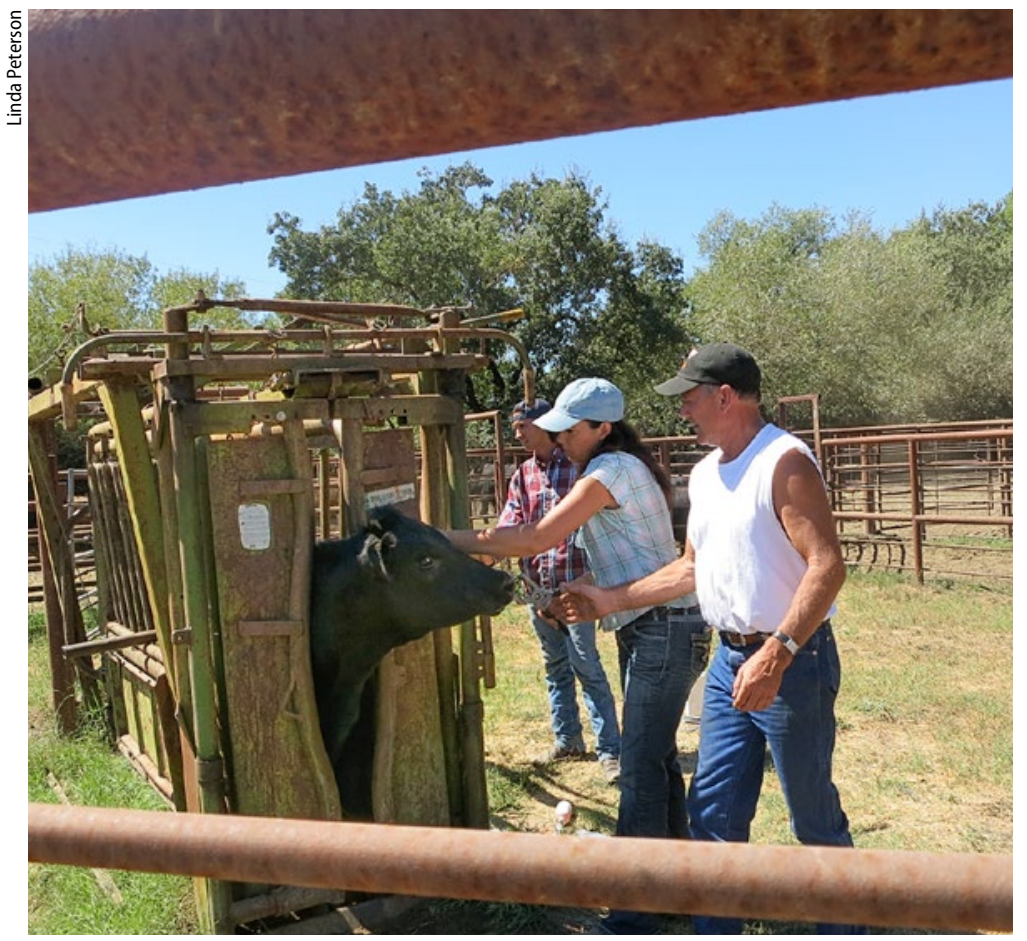

Beginning Farmer and Rancher (BFR) participant Kelly Osman tags the ear of a pregnant Black Angus cow, with help from Denner Ranch owner and BFR mentor Terry Lindley (front) and ranch hand Joey Howard (back).

\section{SUSTAINABLE FOOD SYSTEMS STRATEGIC INITIATIVE}

\section{Beginning growers and ranchers}

Tarming as a way of life is waning in Sonoma - County, as agricultural land is converted to housing and the average age of growers nears 60 years. "We need to bring new farmers into the business," says Stephanie Larson, director of UCCE Sonoma County.

To do just that, she launched a Beginning Farmer and Rancher program with a 3-year grant from the United States Department of Agriculture (USDA) beginning in 2011. The program includes hands-on experience in production and business planning (including marketing, organic certification, permitting and regulations, and lending) as well as mentoring by local master growers and ranchers. "Farming is challenging," Larson says. "People can have a great idea but often fail due to the business end."

Just as importantly, participants get access to land. They can lease vacant county land, and can use a website that matches new growers and ranchers with private landowners who want to lease acreage. In addition, a training farm - known as an incubator farm - is in the works, which will help participants get started by, for example, providing shared equipment, mentoring, and a lower initial lease rate.

"We have folks who already have land and are hoping to reinvent and save their family farms, or who are switching careers to grow local food," says Linda Peterson, UCCE Beginning Farmer and Rancher program coordinator. About half of the 43 participants to date are minorities, women or lowincome, and most are now working in the agricultural field. "They've increased production, started farms or are working on farms," she says. Their operations include local hard cider, dry-farmed tomatoes, sheep and goat cheese, and agricultural tourism.

Now, Larson and Peterson are integrating their Beginning Farmer and Rancher program into the sustainable agriculture program at Santa Rosa Junior College, which will ensure that the program continues long after the USDA grant is finished.

\section{HEALTHY FAMILIES AND COMMUNITIES} STRATEGIC INITIATIVE

\section{Eating Smart, Being Active}

Tost of us know the basics of a healthy lifestyle 1 _ - eat plenty of fruits and vegetables, exercise regularly, and so on - but knowing what do to and 
actually doing it are far from the same thing. To help Californians make healthy choices that stick, UC ANR administers and UCCE delivers the federally funded Expanded Food and Nutrition Education Program (EFNEP) statewide.

As part of the program, UCCE nutrition educators teach adult classes with the Eating Smart, Being Active curriculum, which was developed by EFNEP and UCCE staff at UC Davis and Colorado State University. Used by Cooperative Extension nationwide, the curriculum consists of eight 1-hour classes that help people make healthy lifestyle choices. Sessions include "Get Moving!," "Vary Your Veggies, Focus on Fruit," and "Make Half Your Grains Whole."

In 2013, this program reached more than 9,000 low-income families in California. "Half of participants now eat three or more servings of vegetables and two or more servings of fruit per day," says Connie Schneider, director of UC ANR's Youth, Families and Communities statewide program, which includes EFNEP. "This is a remarkable improvement."

Juana Gonzalez of Colusa is a standout EFNEP graduate. She went from eating hardly any produce to enjoying two cups each of vegetables and fruit a day, and now seasons her food with herbs and spices instead of salt, and drinks water instead of soda. She also bumped up her daily exercise from less than half an hour to more than an hour. Her reward? Gonzalez has lost weight and no longer needs high blood pressure medication. "I feel better and, best of all, my teenage daughter is making healthy lifestyle changes with me," she says.

Besides embracing her new lifestyle, Gonzalez inspires others to do the same. "Now Juana comes to the first class of my other sessions to say, 'Look what this did for me,'" says Sonia Rodriguez, EFNEP nutrition educator at the Altami Learning Center in Colusa. "She's a great advocate."

\section{SUSTAINABLE NATURAL ECOSYSTEMS STRATEGIC INITIATIVE}

\section{Training conservation volunteers}

Tust an hour's drive north of Los Angeles, the Tejon Ranch Conservancy was overwhelmed with requests to visit the 240,000 acres of oak woodland, desert, fir forest and chaparral that it manages. This range of habitats makes the ranch a hotspot of biological diversity, with big draws such as condors, pronghorn, mountain lions and stunning wildflower displays. "This is a huge piece of land that is really unique in California because there has been no intensive recreation - ranching can be more compatible with endangered species than a lot of people tromping around," says Sabrina Drill, UCCE natural resources advisor in Los Angeles County. "Because this is still working land, all public access needs to be guided, and they couldn't keep up with the demand."

Drill is also co-director of UC ANR's new California Naturalist Program, which partners with local organizations statewide to engage the public in the study and stewardship of California's natural resources. This makes the program a perfect fit with the Tejon Ranch Conservancy. "They need help with monitoring and restoration projects, and with allowing the larger community to come and enjoy the land," she says. "They thought they were going to have to develop their own

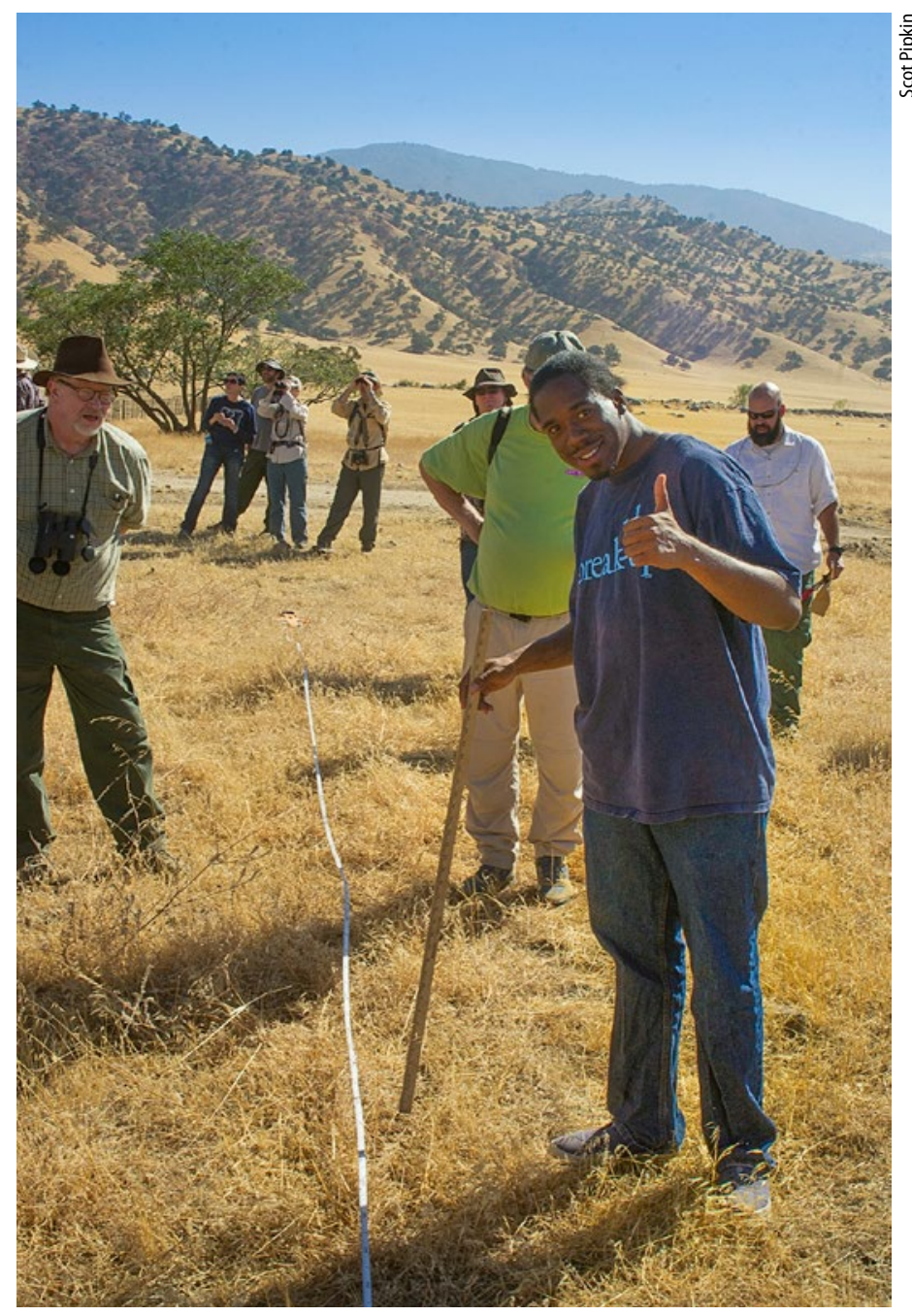

Tejon Ranch Conservancy volunteer Deonsa Taylor measures residual dry matter on rangeland, which will help manage grazing on this working cattle ranch.

curriculum so they were excited to have a UC-vetted, sciencebased stewardship education program already available."

The curriculum includes 40 hours of class time and field training, as well as individual capstone service projects. The first Tejon Ranch class was held in the fall of 2013, and many of the projects - which included acorn monitoring, pronghorn surveys, a weather station and a camera network to monitor wildlife — are ongoing. Training will continue yearly, and graduates will also guide wildflower and natural history tours, and, ultimately, staff the ranch's nature center.

"We have 20 graduates who are already providing valuable citizen science work," says Scot Pipkin, public access coordinator of the Tejon Ranch Conservancy. "This program provides an excellent foundation for our volunteers."

WATER QUALITY, QUANTITY AND SECURITY STRATEGIC INITIATIVE

\section{Balancing grazing and watersheds}

Today's harmony between grazing and public lands in the Bay
Area stems from UCCE work that began in the 1990s. Back 
then, it looked like the region's grazing would soon be a thing of the past. "There were concerns that cattle were a vector for pathogens in drinking water," says Sheila Barry, UCCE livestock and natural resources advisor for the San Francisco Bay Area. "The San Francisco Public Utilities Commission (SFPUC) wanted to get rid of grazing on 40,000 acres in the East Bay."

Ranchers, some of whom had worked this land for three generations, asked Barry for help. "We had just 60 days," Barry says. Coincidentally, UCCE had just finished a statewide survey on cattle and Cryptosporidium, a fecal pathogen. "This was the key," she says. "We had the data to help answer the SFPUC's questions about grazing and drinking water safety."

The survey showed that Cryptosporidium shedding was most common in calves younger than 4 months, helping Barry and her collaborators develop a grazing plan for the SFPUC land. For example, calving has to be done by the beginning of November. "This way the young cattle are old enough not to shed by the time it rains enough for runoff to load water with pathogens," she says.

Another facet of the grazing plan is keeping cattle away from waterways. "We sat with the ranchers and went over their riparian areas and streams, and fine-tuned cattle's access to these waters," Barry says. Ongoing monitoring ensures that ranchers maintain the fences that keep herds where they should be.

Buy-in was also critical to the plan's success. "We included all stakeholders from the beginning, taking them on rangeland tours and explaining the management," Barry says. Based on the UCCE plan, in 1999 the SFPUC adopted best management practices (BMPs) for grazing watersheds. Besides preserving the livelihoods of the ranchers who came to Barry for help, the BMPs set the stage for continued grazing on public lands throughout the Bay Area.

\section{ENDEMIC AND INVASIVE PESTS AND DISEASES STRATEGIC INITIATIVE}

\section{Preparing for Africanized bees}

nother UCCE project in the 1990s has had lasting benefits for the alfalfa seed industry. California is among the nation's top producers of alfalfa seed, with 38,000 acres in the Central and Imperial valleys that yield 11,000 tons of seed per year.

At the time, alfalfa seed growers were worried that the extremely defensive Africanized honey bee would soon reach the San Joaquin Valley. So they asked Shannon Mueller, UCCE farm advisor in Fresno County, to help them start using the alfalfa leafcutting bee. Unlike the European honey bee, the alfalfa leafcutting bee does not breed with Africanized bees and so cannot inherit their aggression.
While leafcutting bees were already widely used in Canada and the Pacific Northwest, no one knew how they would survive the hot temperatures and low humidity of California's interior valleys. Moreover, an alfalfa seed company had already tried to introduce them to California without success. "It was called a million dollar mistake," Mueller says.

But this time it worked. Why? "The growers and seed companies all sat down at the same table with UCCE as the conduit, sharing research-based information on what did and didn't work," Mueller says. "We learned how to manage the leafcutting bee for our conditions." This was essential because while honey bees are managed by beekeepers, leafcutting bees are managed by growers and seed companies.

Today, the combination of leafcutting bees and European honey bees is a standard in California's alfalfa seed industry. Besides giving growers an additional pollinator, the leafcutting bee increased yields by about 300 pounds an acre. This is partly because the bees pollinate alfalfa more efficiently and partly because they complement honey bees. For example, irrigation discourages honey bees but not the leafcutting bees.

"Growers have said that without the alfalfa leafcutting bee, they wouldn't be in the alfalfa seed business anymore," Mueller says. "This was a phenomenal project — it's a standout in all my years in Cooperative Extension."

-Robin Meadows of Seed Services, Inc. in Fresno checks the flight and nesting activity of alfalfa leafcutting bees, which nest in this trailer.

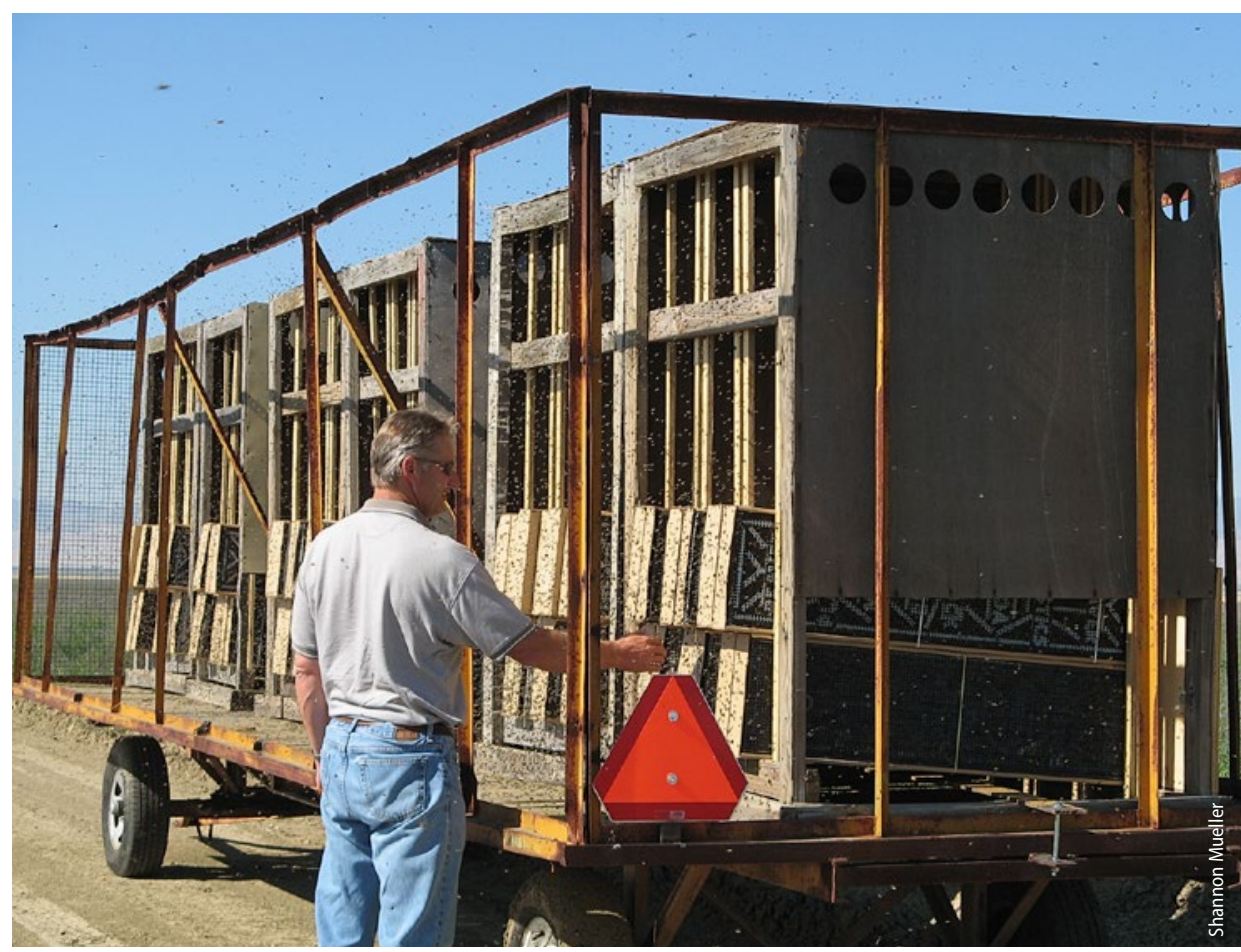

